
\title{
РОЛЕВЫЕ ИГРЫ КАК ОБРАЗОВАТЕЛЬНАЯ ТЕХНОЛОГИЯ В ОБУЧЕНИИ ИНОСТРАННЫМ ЯЗЫІКАМ В МЕДИЦИНСКОМ ВУЗЕ
}

\section{ROLE PLAY AS AN EDUCATIONAL TECHNIQUE OF FOREIGN LANGUAGE TEACHING IN A MEDICAL UNIVERSITY}

\section{T. Baeva \\ K. Kubacheva \\ N. Koroleva}

Summary: This article considers some issues related to the use of role play technique as a factor to enhance learning efficiency in the process of foreign language teaching in a medical university. The purpose of the study is to analyze the influence of using this interactive role play technique on acquiring foreign language communicative competence in the field of professional activity. Role play technique allows to include foreign language learning directly in the model of the future health professionals' work in hospitals, community health centers and private practice. Health professional activities can be represented as a dynamic system of specific actions aimed at achieving the ultimate goal: curing the patient. So, we use a huge variety of exercises for simulation of real communication between hospital team members and a patient. The authors share their experience in using role-play technology organized in the process of distance learning with the use of online platform and a variety of "offline" and "online" exercises to simulate real communication between healthcare professionals and patients that allows to optimize the educational process without losing the quality of training.

Keywords: role-play, the process of real communication in medical practice, "offline" and "online" exercises, foreign-language professional communicative competence.
Баева Тамара Ахматовна

К.п.н., дочент, Северо-Западный государственный медицинский университет им. И.И. Мечникова

(Санкт-Петербург)

tamarabaeva@mail.ru

Кубачева Кабият Ибрагимовна

К.п.н., дочент, Северо-Западный государственный медицинский университет им. И.И. Мечникова

(Санкт-Петербург)

gabib101155@mail.ru

Королева Наталия Геннадьевна

К.п.н., дочент, Северо-Западный государственный медицинский университет им. И.И. Мечникова

(Санкт-Петербург)

Nataliya.Koroleva@szgmu.ru

Аннотация: В статье рассматриваются вопросы образовательных технологий в обучении иностранным языкам и, в частности, ролевой игры как фактора повышения эффективности обучения иностранным языкам в медицинских вузах. Анализируется влияние использования интерактивной ролевой игры на овладение иноязычной коммуникативной компетенцией в сфере профессиональной деятельности. Отмечается, что использование ролевых игр позволяет включать изучение иностранного языка непосредственно в модель будущей работы медицинских работников в медицинских учреждениях: больницах, поликлиниках, частной практике. В статье представлены образцы разнообразных упражнений, разработанных для отработки у студентов медицинского вуза речевых умений и навыков, используемых при проведении ролевых игр. Авторы делятся опытом применения технологии ролевой игры, организованной в дистанционной форме с помощью онлайн-платформы, позволяющей оптимизировать учебный процесс без потери качества обучения.

Ключевые слова: ролевая игра, процесс реального общения на иностранном языке в медицинской практике, упражнения «оffine» и «online», иноязычная профессиональная коммуникативная компетенция.

\section{Введение}

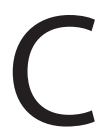
овременные процессы глобализации, текущие изменения в социальных отношениях, быстрый темп инноваций, когда в повседневной медицинской практике используются как российские, так и зарубежные передовые технологии и методы, все это предъявляет высокие требования к уровню профессиональной иноязычной коммуникативной компетенции медицинских работников.

Личное (международные конференции, семинары, научные стажировки) и виртуальное общение (электрон- ная почта, социальные сети, мессенджеры WhatsApp, Telegram или Viber, сеансы телемедицины, проведение вебинаров и видеоконференций) требует повышения уровня иноязычной подготовки будущего специалиста в области здравоохранения [1].

Опыт реализации академической мобильности СЗГМУ им. И.И. Мечникова (студенческие обмены и стажировки, летние и зимние школы) позволяет сделать вывод о том, что формирование профессиональной иноязычной компетенции как основы профессионально-ориентированного общения дает возможность студентам-медикам общаться в различных ситуациях, в том 
числе и за рубежом.

Рассматривая вопросы профессионально-ориентированного обучения иностранному языку в неязыковых вузах, С.Г. Тер-Минасова отмечает, что цель обучения говорению на основе профессионально-ориентированных текстов - «не только учить понимать кем-то созданные тексты, но и создавать, порождать собственную речь», без чего невозможно реальное общение $[11$, c. 25]. Большое внимание вопросам речевой компетенции будущего врача в процессе обучения иностранному языку уделяет М.Б. Мусохранова, которая полагает, что ведущей целью обучения иностранному языку в медицинском вузе выступает формирование речевой компетенции, как профессионального качества врача [10]. Разделяя позицию М.Б. Мусохрановой, что содержание обучения должно отражать содержание профессиональной деятельности и специфику речи врача, мы также строим обучение на основе общения, когда процесс обучения является моделью процесса коммуникации.

Мы полагаем, что одним из эффективных путей формирования коммуникативной компетенции студентов является технология ролевых игр, позволяющая непосредственно включить процесс обучения иностранному языку в модель будущей трудовой деятельности [3].

Цель данной статьи - рассмотреть некоторые вопросы, связанные с использованием технологии ролевой игры как фактора повышения эффективности обучения в процессе преподавания иностранного языка в медицинских вузах.

Проблема применения ролевых и деловых игр в обучении иностранному языку находит широкое освещение в зарубежной (Д. Браун, Дж. Ладусс, К. Ливингстон, Д. Хармер и др.) и отечественной литературе (Е.П. Белкина, Г.С. Демидова, Г.А. Китайгородская, Р.П. Мильруд и др.). Для того, чтобы научить иностранному языку как средству профессионального общения, необходимо активно использовать иностранный язык в живых, естественных ситуациях, создавая на занятии обстановку реального общения. Использование ролевых игр активизирует речевую деятельность участников, так как «погружает» в ситуации, где необходимость что-то сказать, спросить, доказать и обсудить.

Р.П. Мильруд определяет ролевую игру как «методический прием, относящийся к группе активных способов обучения практическому владению иностранным языком» $[8$, с. 8]. Ролевые игры используются как для работы над отдельными аспектами, так и для выполнения более сложных задач. Согласно концепции Джиллиана Ладусса, ролевая игра выступает эффективным средством создания мотива к иноязычному общению, она использует различные коммуникативные техники и развивает беглость в языке, помогает улучшить навыки говорения в любой ситуации [16].

Е.П. Белкина считает, что в процессе игры происходит обогащение словарного запаса, автоматизация применения разговорных клише, развиваются коммуникативные навыки, тренируется память, воспитывается уважение к культуре изучаемого языка [4].

Изучая вопросы коммуникативного подхода, Дуглас Браун отмечает, что ролевая игра становится одним из педагогических средств создания «настоящей» коммуникации в учебной аудитории, обучая студентов беглости языка, а не только ее правильности. Таким образом, преподаватели снабжают обучающихся инструментами создания неподготовленной речи за пределами аудитории. Главным является стимулирование студентов к изучению иностранного языка на протяжении всей жизни, а не только при выполнении упражнений и заданий в аудитории [14, с. 274].

Рассматривая ролевую игру как самую верную модель общения, Д.Б. Эльконин полагает, что она имитирует реалии окружающего мира в самых существенных чертах, кроме того, в ролевой игре имеет место речевое и неречевое поведение коммуникантов [12].

\section{Методы}

Анализ работ перечисленных авторов, а также многолетний опыт работы в неязыковом вузе позволили сделать вывод о больших потенциальных возможностях, заложенных в ролевой игре, и принципиальной целесообразности ее использования в процессе формирования профессиональной иноязычной компетенции, необходимой для будущей профессиональной межкультурной коммуникации.

Ролевые игры, являясь одной из форм реализации коммуникативного подхода, нацелены на взаимодействие участников в процессе общения, то есть осознание возможных вариантов развития диалогов; уяснение и достижение общей коммуникативной цели; расширение языковой компетенции одного участника коммуникации за счет общения с другими участниками [7].

Обучение иностранному языку студентов медицинских вузов предусматривает развитие коммуникативной компетенции, т. е. умения понимать и порождать высказывания на иностранном языке в соответствии с конкретными сферой, тематикой и ситуацией общения. 
Занятия с первокурсниками показывают, что треть студентов испытывают трудности при общении из-за отсутствия необходимой информации, неумения выражать мысли языковыми средствами. Вслед за А.А. Миролюбовым мы рассматриваем диалог «как один из видов речевой деятельности, которым надо овладеть в процессе обучения» [9, с. 211-217]. Известно, что диалогическая речь предполагает следующие умения: свободно пользоваться определенными штампами речи; понимать речь собеседника; быстро реагировать на высказывание собеседника; поддерживать разговор. Поэтому, на начальных этапах обучения иностранному языку при обучении диалогической речи мы используем диалоги-образцы, которые дают студенту четко понять, высказывания какого характера ему необходимо использовать при составлении реплик, и не ограничивают его в выборе смысловой наполненности диалога. Однако, уже через месяц становится актуальным обучение диалогической речи на основе пошагового составления диалога или посредством создания ситуации общения, приближенной к реальной [3].

Дефицит учебного времени требует находить пути рациональной организации речевой практики, которая в максимально сжатые сроки давала бы реально ощутимые результаты. Поэтому, мы создаем на занятии обстановку реального профессионального общения. Напримep,

- ролевые игры - «врач-врач/ординатор/медсестра/больной» и т. д.;

- обсуждения/представления историй болезни;

- обсуждения/представления различных клинических патологий;

- обсуждения/представления новостей медицины;

- научные дискуссии по вопросам теории и практики медицины с привлечением иностранных специалистов;

- участие студентов в программах академической мобильности [1].

Отмечая, что, ролевая игра определяет модель речевого поведения, свойственную исполнителю в различных ситуациях, Д.Б. Эльконин подчеркивает необходимость предварительной работы с языковым материалом, его тренировку в упражнениях [12, с. 69].

Опираясь на концепцию Г.А. Китайгородской, что непрерывное общение организуется через решение множества коммуникативных задач, представленных в коммуникативных упражнениях [6], преподавателями кафедры были созданы упражнения для решения конкретных учебных задач на определенном языковом и речевом материале, которые затем комбинировались в сценарии занятия. Данный комплекс упражнений представлен в учебно-методических пособиях, созданных на кафедре и используемых в курсе обучения студентов медицинских специальностей [15; 17].

Рассмотрим некоторые виды упражнений при проведении ролевой игры «Taking medical history»:

1. Complete the conversations using the information from the case in the box.

A 25 year old man comes to GP's office with the complaint of a bad sore throat for 2 days. He has felt chills and fever today but has not measured his temperature. He has some pain on swallowing. He has a slight runny nose and denies cough. He feels weak and tired.

Doctor: How $?$

Patient: I'm not well and I feel chills

Doctor: Have $?$

Patient: No, I haven't. I think I have a fever.

Doctor: Do $?$

Patient: I have some pain on swallowing.

Doctor: , haven't you?

Patient: Yes, it hurts when I talk.

Doctor: Do $?$

Patient: No cough, but a slight runny nose. $\searrow$

2. Watch the video and write down 12 Questions Doctors Ask Patients in English https://www.youtube.com/watch?v=51 wvlhwDi00

3. Study this extract from a case history. Work in pairs. Roleplay taking medical histories of the following cases:

Student A: Play the part of the patient. Base your replies on the information given in this extract.

Student B: Play the part of the doctor. Find out what the patient is complaining of. 


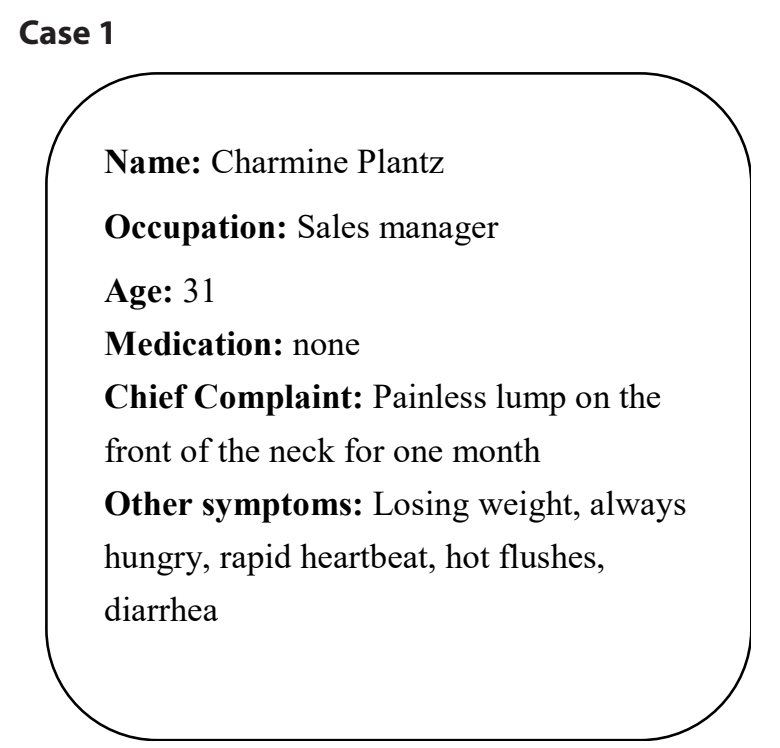

Case 2

Name: Chris Brown Occupation:

Office manager

Age: 25

Medication: Strepsils

Chief Complaint: A bad sore throat

for 2 days

Other symptoms: Chills and fever today but has not measured his temperature. He has some pain on swallowing. He has a slight runny nose and denies cough. He feels weak and tired.

$\searrow$

Использование ролевых игр помогает студентам уменьшить языковой барьер, автоматизировать навыки применения разговорных клише, обогатить словарный запас, учиться реагировать на реплики собеседника, формировать навыки спонтанной речи [18].

Соглашаясь с концептуальными положениями О.Ю. Искандаровой, мы полагаем, что перед преподавателями иностранного языка медицинских вузов стоит задача сформировать у студентов следующие умения: общаться с коллегой; общаться с пациентом; действовать в нестандартных ситуациях [5].

Поэтому, при формировании коммуникативной компетенции мы считали необходимым выработать у студентов следующие умения и навыки для ее реализации:

- при общении с коллегой уметь слушать и отвечать на вопросы, корректно и вежливо вести дискуссию, выражая свои мысли и аргументы на ино- странном языке и т.д.;

- при беседе с пациентом уметь правильно задавать вопросы, используя вежливую форму вопросов, обычно применяемых в беседе «врач - пациент», выслушивать пациентов, ответить на вопрос, выражая сочувствие, успокоить пациента, объяснив его проблему и сняв его тревоги и т.д.;

- действуя в чрезвычайных ситуациях уметь сконцентрироваться и сформулировать свою мысль на иностранном языке, найти необходимую информацию, дать правильную оценку ситуации и т.д.;

- соблюдать этику делового общения - правильно строить сообщения на переговорах с зарубежными коллегами, во время выступлений и презентаций на научной конференции.

Очень важным во время ролевых и имитационных игр является то, что обучение языку происходит через квазипрофессиональную деятельность, а специальности - через язык. Выполняя в игровых ситуациях отдельные функции медицинских работников: врача, парамедика, медсестры, медицинского регистратора, связанные с профессиональным общением, и выступая в роли пациентов с различными медицинскими проблемами, студенты овладевают навыками межличностного и профессионального общения [2; 3].

Особое внимание мы уделяем формам межличностных коммуникаций - диалогам, ролевым и ситуационным играм, дискуссиям на профессиональные темы и «круглым столам». Данные формы позволяют формировать профессиональную иноязычную компетенцию не только в процессе живого общения в учебной аудитории, но и при максимальном использовании возможностей ЭИОС, средств и форм виртуального общения: телекоммуникаций (видеоконференции, «круглые столы», вебинары, телемосты и телеконсилиумы), внедряя, таким образом, онлайн-курсы в учебную аудиторию [1]. Интересны в этом плане исследования Н.И. Алмазовой, С.С. Андреевой и Л.П. Халяпиной, которые изучают различные модели, объединяющие онлайновое и офлайновое образование для подготовки студентов к эффективному использованию академического дискурса на английском языке как языка глобального общения [13].

Особенно актуальной эти формы занятий стали в настоящее время, когда в условиях угрозы распространения коронавирусной инфекции большинство университетов и колледжей приняли решение о переходе на дистанционное обучение. Если в очной форме обучения ролевые игры применяются достаточно давно, то для дистанционной формы, в условиях удалённости субъектов обучения друг от друга, эта новая технология, и она ещё не получила столь широкого распространения. Для организации учебного процесса он-лайн мы выбра- 
ли платформу Zoom за простоту использования - вход осуществляется через имеющуюся электронную почту. Упрощенная видеоконференцсвязь позволяет запускать, присоединяться и участвовать в конференциях с использованием любого устройства. И самое главное, она рассчитана на групповое обучение, благодаря встроенным инструментам коллективной работы, множество участников могут совместно использовать свои экраны и делать заметки для достижения максимальной интерактивности.

При изучении темы «Hygiene» мы объединили 2 группы студентов, обучающихся на разных факультетах, для проведения ролевой игры в форме Ток-шоу «COVID-19. The Battle for Humanity». Как мы знаем, «классическое» ток-шоу представляет собой треугольник: ведущий приглашённые собеседники (эксперты) - зрители в студии (в нашем случае, это студенты, находящиеся территориально удалённо друг от друга). Схема игры довольно проста: герои, зрители, ведущий, вопросы и ответы. Задача ролевой игры в форме ток-шоу - активизировать восприятие темы с помощью формы диспута, острых вопросов, высказывания различных точек зрения. Были выбраны 2 ведущих из числа лучших студентов, 4 студента Медико-профилактического факультета выступали экспертами-эпидемиологами, 4 студента Лечебного факультета представляли медицинских работников. Все остальные студенты принимали участие в дискуссии, задавая вопросы и оценивая санитарно-гигиенические мероприятия, проводимые в регионах их нынешнего пребывания. В процессе проведения видеоконференции были обсуждены следующие вопросы:

- Risk of Coronavirus global spread is very high;

- Urgent need for developing COVID-19 vaccine;

- Cleaning and hygiene tips to help keep the COVID-19 virus;

\section{- Survey reveals that one third of Russians are coronavirus skeptics; \\ - How Will the World Be Different After COVID-19.}

Исходя из вышеизложенного, можно сделать вывод о том, что онлайн-платформа является таким же эффективным дидактическим средством, как и традиционное. В процессе проведения видеоконференции студенты следовали основным тактикам игрового поведения, которые по своей сути соответствуют типам речевых упражнений: сначала выполняли речевую задачу, организованную в виде игры, а затем - коммуникативную.

\section{Выводы}

Таким образом, можно с уверенностью говорить о том, что ролевые игры, как образовательная технология в обучении иностранным языкам в медицинских вузах, создают среду образовательного общения, которая характеризуется открытостью, взаимодействием участников, равенством их аргументов, накоплением совместного знания и являются фактором повышения эффективности овладения иноязычной коммуникативной компетенцией в сфере будущей профессиональной деятельности.

Использование разнообразных упражнений для симуляции реального общения в сфере медицины дает студентам возможность индивидуально расширить и углубить свои языковые знания и навыки и применить в общении не только их, но и все полученные на практике знания в области медицины.

Применение технологии ролевой игры организованной в дистанционной форме с помощью онлайн-платформы позволяет оптимизировать учебный процесс без потери качества обучения.

\section{ЛИТЕРАТУРА}

1. Баева Т.А. Методика формирования профессиональной иноязычной компетенции студентов медицинских вузов в условиях информационно-образовательной среды: дис. ... канд. пед. наук. - Нижний Новгород, 2013. - 220 с.

2. Баева Т.А., Жаворонкова Е.М., Сергопольцева Е.О. Профессионально - ориентированные образовательные технологии в обучении студентов медицинских вузов иностранным языкам. // Психология и педагогика 21 века. Современные проблемы и перспективы: сб. ст. междунар. науч.-практ. конф., 2018. - C. 41- 45.

3. Баева Т.А., Кубачева К.И. Деловые и ролевые игры в обучении студентов медицинского вуза иностранному языку. // Евразийский научный журнал. 2016. - № 11. - С. 208-213.

4. Белкина Е.П. Использование ролевых игр при обучении иностранному языку студентов неязыковых направлений подготовки. // Филологические науки. Вопросы теории и практики. - 2013. - № 61 (24). - С. 36-39.

5. Искандарова 0.Ю. Теория и практика формирования иноязычной профессиональной коммуникативной компетентности специалиста: автореф. дис. ... д-ра пед. наук. - Оренбург, 2000. - 38 с.

6. Китайгородская Г.А. Методика интенсивного обучения иностранным языкам: учеб. пособие. 2-е изд., испр. и доп. - М.: Высшая школа; Школа Китайгородской, 2009. - 221 с.

7. Мильруд Р.П., Максимова И.Р. Обучение культуре и культура обучения языку // Иностранные языки в школе. - 2012. - № 5. - С. 12-19. 
8. Мильруд Р.П. Организация ролевой игры на уроке. // Иностранные языки в школе. - 2004. - № 3. - С. 8.

9. Миролюбов А.А. История отечественной методики обучения иностранным языкам: учеб. пособие для студентов вузов, обучающихся по направлению «Лингвистика и межкультур. коммуникация». - М.: Ступени: ИНФРА-М, 2002. - 446 с.

10. Мусохранова М.Б. Формирование речевой компетентности будущего врача в процессе обучения иностранному языку: автореф. дис. .... канд. пед. наук. Омск, 2002. -23 c.

11. Тер-Минасова С.Г. Язык и межкультурная коммуникация: учеб. пособие. - М.: Слово/Slovo, 2008. - 264 с.

12. Эльконин Д.Б. Психология игры. - 2-е изд. - М.: Гуманит. изд. центр ВЛАДОС, 1999. - 360 с.

13. Almazova N., Andreeva S., Khalyapina L. The integration of online and offline education in the system of students' preparation for global academic mobility. // Communications in Computer and Information Science. - 2018. - T. 859. - C.162-174.

14. Brown H.D. Principles of Language Learning and Teaching. /5th Edition. - Upper Saddle River: Pearson Education. - 2015. - 668 p.

15. English for medicine: английский язык для студентов медицинских специальностей: учебно-методическое пособие. Часть І. / Е.Г. Липатова, Н.Г. Ольховик, Т.А. Баева, Е.В. Мушенко, Л.А. Степанян. - СПб.: Изд-во СЗГМУ им. И.И. Мечникова, 2016. - 80 с.

16. Ladousse G.P. Role Play. - Oxford: Oxford University Press, 2004. - $181 \mathrm{p}$.

17. Working in medicine: английский язык для студентов медицинских специальностей: учебно-методическое пособие. Часть ІІ. / Е.Г. Липатова, Н.Г. Ольховик, Т.А. Баева, К.И. Кубачева, Е.В. Мушенко. - СПб.: Изд-во ФГБОУ ВО СЗГМУ им. И.И. Мечникова, 2017. - 84 с.

18. Демидова Г.С. Ролевая игра на уроках иностранного языка [Электронный ресурс] /Г.С. Демидова //Социальная сеть работников образования. URL: http://nsportal.ru/shkola/inostrannye-yazyki/library/201 2/02/12/rolevaya-igra-na-urokakhinostrannogo-yazyka. (дата обращения: 27.11.2020).

(c) Баева Тамара Ахматовна (tamarabaeva@mail.ru), Кубачева Кабият Ибрагимовна (gabib101155@mail.ru),

Королева Наталия Геннадьевна (Nataliya.Koroleva@szgmu.ru).

Журнал «Современная наука: актуальные проблемы теории и практики»

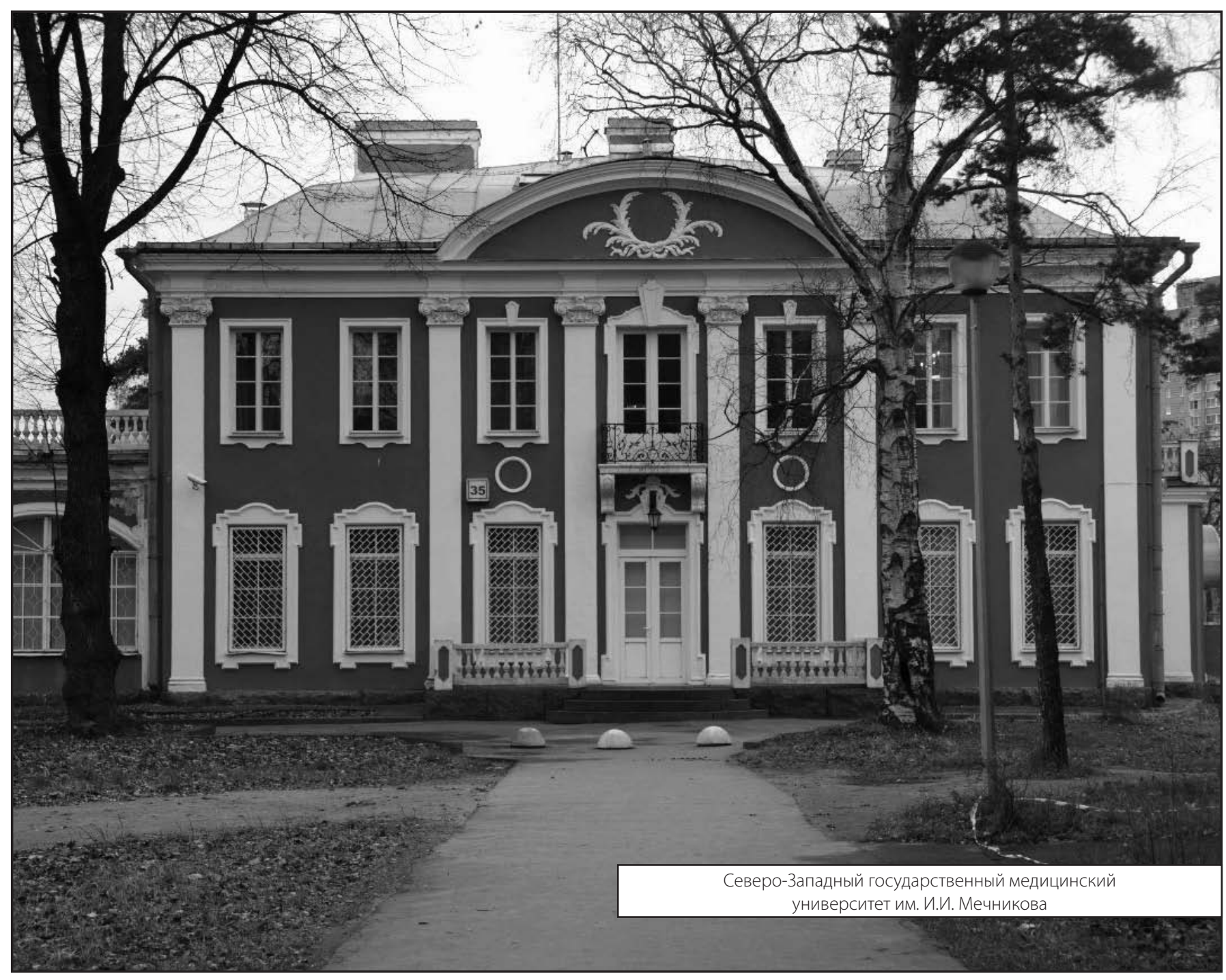

